\title{
Physics of Energy Efficient Buildings
}

\author{
David Hafemeister \\ Physics Department \\ Cal Poly University \\ San Luis Obispo, CA 93407
}

\begin{abstract}
A scaling model shows that that the free temperature offset between inside and outside increases with the size of buildings. Reducing the lossiness in buildings offers three energy savings advantages: (1) reduce the multiplicative term, (2) increase the free-temperature subtractive term, and (3) cater to the degree-day distribution. Thermal storage can be made to transfer sufficient heat of the day into the coolth of the night. The daily passive solar input is modeled by integrating over the change in zenith angle during the day. Passive solar storage is sized to give a 12 -hour time constant.
\end{abstract}

\section{BASIC PHYSICS}

"Heat goes by itself from the hotter body to the colder body."

"Insulate before you insolate."

"Glass plus mass prevents you from freezing...."

Energy use in buildings accounts for $40 \%$ of total energy use. Reducing this fraction could significantly stabilize national security, improve the environment and enhance the national economy. Residential and commercial buildings consumed energy totaling 37.5 quads/yr in 2001, at a cost of $\$ 300$ billion/yr. Buildings dominate the use of electricity at 26 quads/yr, which is $67 \%$ of US electricity consumption of 40 quads/yr. Buildings built prior to the oil embargo of 1973-74 were often an energy disaster, built without insulation, wasting winter heat and summer air conditioning alike. New buildings now consume one-half their former level per square feet because energy intensity of big buildings has dropped from 270,000 to $100,000 \mathrm{Btu} / \mathrm{ft}^{2}-\mathrm{yr}$ of primary energy. ${ }^{1}$ But these gains are being countered by homes that have grown from an average of $1400 \mathrm{ft}^{2}$ in 1970 to today's $2225 \mathrm{ft}^{2}$. This increase is caused by more bathrooms and other design extras. In 2000 , US home ownership stood at $66 \%$, which means that for $1 / 3$ of residences the landlord makes the energy decisions while the renter pays the bills.

Before the oil embargo, leaders of the expansive and burgeoning building industry were not engaged in coordinated energy research. The embargo changed this, 
catalyzing serious research and development at the Lawrence Berkeley Laboratory and Princeton University on the use of energy in buildings. The State of California established the first energy standards for buildings in 1975. Many states and the federal government followed California's lead.

\section{Linear Heat Transfer}

Summer heat gains and winter heat losses are caused by temperature differences through walls, ceilings and floors (50-70\%) and windows (15-25\%), and by air infiltration $(20-30 \%)$. Thermal resistance, or the $R$-factor, is defined in terms of a unit area of $1 \mathrm{~m}^{2}\left(1 \mathrm{ft}^{2}\right)$ area. For material of thickness $L, R$ is defined as $R=L / k$, where conductivity is $k$. For an electrical resistor, the resistance $R$ takes into account the three physical dimensions of the device, but thermal resistance $R$ is described by a thickness, a material type and a basic area unit. Thus a builder purchasing insulation may specify $100 \mathrm{ft}^{2}$ of R13 insulation for 2 " x 4" stud walls, R19 for 2" x 6" stud walls, but an electrician does not specify area when buying a 100 -ohm resistor. The thermal transmittance $U$-factor, is defined as the inverse of thermal resistance $R$, or $U$ $=1 / R$. Heat flow through a slab of material is thus given by

$$
d Q / d t=A \Delta T / R=U A \Delta T .
$$

SI and English units are as follows: Heat flow, watts (Btu/hour); area, $\mathrm{m}^{2}\left(\mathrm{ft}^{2}\right) ; \Delta T,{ }^{\circ} \mathrm{C}$ $\left({ }^{\circ} \mathrm{F}\right) ; R, \mathrm{~m}^{2}-{ }^{\circ} \mathrm{C} / \mathrm{W}\left(\mathrm{ft}^{2}-{ }^{\circ} \mathrm{F}-\mathrm{h} / \mathrm{Btu}\right)$ and $U, \mathrm{~W} /\left(\mathrm{m}^{2}-{ }^{\circ} \mathrm{C}\right)\left(\mathrm{Btu} /\left(\mathrm{h}-\mathrm{ft}^{2}-{ }^{\circ} \mathrm{F}\right) . \mathrm{R} 19\right.$ walls and $\mathrm{U} 1$ windows in the United States become R3.4 and U6 elsewhere. The conversion factors between the two cultures are

$$
R_{\mathrm{SI}}=R_{\text {English }} / 5.67 \text { and } U_{\mathrm{SI}}=5.67 \times U_{\text {English }} .
$$

\section{Series and parallel heat paths}

The R-value of materials layered in series is the sum of the $R$-values for the individual layers. For a wall with two layers of plasterboard and a layer of insulation,

$$
R_{\text {total }}=R_{1}+R_{2}+R_{3}=L_{1} / k_{1}+L_{2} / k_{2}+L_{3} / k_{3}=1 / U_{\text {total }} .
$$

Buildings have inside-to-outside, parallel heat paths through walls, windows, roofs, floors and infiltration. Total heat flow is the sum of parallel heat flows,

$$
d Q / d t_{\text {total }}=d Q / \mathrm{d} t_{1}+d Q / d t_{2}+d Q / d t_{3}=\left(U_{1} A_{1}+U_{2} A_{2}+U_{3} A_{3}\right) \Delta T .
$$

Two electrical resistors in parallel have an effective resistance of $R_{\text {eff }}=R_{1} R_{2} /\left(R_{1}+R_{2}\right)$. If $R_{1}$ is much larger than $R_{2}$, the effective resistance is determined from the smaller value, or $R_{\text {eff }} \approx R_{2}$. When combining parallel thermal paths, one needs to take into account the relative area of each, so that $A_{\text {Total }} / R_{\text {eff }}=A_{1} / R_{1}+A_{2} / R_{2}$, where $A_{\text {Total }}=A_{1}$ $+\mathrm{A}_{2}$. If a homeowner tightens $75 \%$ of his R10 house with R1000 insulation, the 
effective R-value of the house does not become R-750, but $\mathrm{R}_{\text {eff }}=40$, only 4 times the initial value. If insulation paths are essentially closed with very large R-values, a point of diminishing returns is reached since infiltration will dominate.

\section{U-Factor for Convection}

Surfaces lose heat by radiation and convection. The rate of heat loss from a surface of area $A$, emissivity $\varepsilon_{1}$, and temperature $T_{1}$ is $\mathrm{d} Q / \mathrm{dt}=\sigma A \varepsilon_{1} T_{1}^{4}$, where $\sigma$ is the StefanBoltzman constant. The same surface will receive radiation from its surroundings, assumed to have emissivity $\varepsilon_{2}$ and ambient outside temperature of $T_{2}$. Convective losses from the surface will be a function of temperature difference $\Delta T=T_{1}-T_{2}$, surface material, wind velocity and geometry. The net rate of heat loss from convection and radiation is given by

$$
d Q / d t=\sigma A\left(\varepsilon_{\mathrm{i}} T_{\mathrm{i}}^{4}-\varepsilon_{2} T_{2}^{4}\right)+h A(\Delta T)^{5 / 4}
$$

where our convection equation is a simple model and $h$ is a convection constant that depends on geometry, air flow and type of surface. Convection can be rewritten as

$$
d Q / d t_{\mathrm{conv}}=h A(\Delta T)^{5 / 4}=\left(h \Delta T^{1 / 4}\right) A \Delta T=U_{\mathrm{conv}} A \Delta T .
$$

The parameter $U_{\text {conv }}=h \Delta T^{1 / 4}$ is relatively constant since $\Delta T^{1 / 4}$ varies slowly. Its inverse varies from $R_{\text {conv-SI }}=0.04-0.2\left(R_{\text {conv-Eng }}=0.2-1\right)$ with larger values outside in the wind and smaller values inside buildings.

\section{U-Factor for Radiation}

Net radiation flow from a surface at temperature $T_{1}$ located in outside ambient temperature $T_{2}$ is

$$
d Q / d t=\sigma A \varepsilon\left(T_{1}^{4}-T_{2}^{4}\right)=\Delta\left(A \varepsilon \sigma T^{4}\right) \approx\left(4 \varepsilon \sigma T^{3}\right) A \Delta T=\left(U_{\text {rad-SI }}\right) A \Delta T
$$

with emissivity assumed equal, $\varepsilon_{1}=\varepsilon_{2}=\varepsilon$. Since temperature difference is typically much less than ambient absolute temperature $\left(\Delta T \approx 30 \mathrm{~K}<<T_{1} \approx T_{2}\right)$, we can linearize the net radiation flow. The net radiation $\mathrm{U}$-factor for room temperature $T_{1}=20^{\circ} \mathrm{C}$ $(293 \mathrm{~K})$ is

$$
U_{\text {rad-SI }}=4 \varepsilon \sigma T_{1}^{3}=(4 \varepsilon)\left(5.7 \times 10^{-8}\right)(293 \mathrm{~K})^{3}=\varepsilon(5.7) .
$$

A blackbody with $\varepsilon=0.9$ gives $R_{\text {rad-SI }}=0.2\left(R_{\text {rad-Eng }}=1\right)$, which is similar to $R_{\text {conv }}$ for conditions outside of buildings. A stove loses heat first by convection and radiation to the inside building surfaces, then by conduction through the walls, windows and infiltration, followed by convection and radiation away from the outside wall surfaces. 


\section{Annual Heat Loss}

Annual heat loss is obtained by arranging the heat loss equation into a product of heat loss rate $\mathrm{d} Q / \mathrm{d} t$ and time spent at that rate $d t$,

$$
\mathrm{d} Q=U A \Delta T d t
$$

Heating severity is proportional to the product $\Delta T \Delta t$. We can get a measure of the severity of the climate by essentially adding the hourly intervals of $\Delta \mathrm{T}$ over a year. For heating, we retain just the terms with $T_{\text {outside }}$ colder than $T_{\text {base }}$ (a defined base temperature) to get degree-hours per year (dh/yr):

$$
d h / y r=\sum_{i=1}^{8760}\left(T_{\text {base }}-T_{\text {outside }}\right)_{\mathrm{i}}(1 \text { hour }) \text {. }
$$

The base temperature $T_{\text {base }}$ is usually defined as $65^{\circ} \mathrm{F}$ which takes into account $3^{\circ} \mathrm{F}$ free temperature from the internal heat of people and appliances. Division by 24 converts degree hours to degree days. The total annual heat loss is a summation over $n$ paths,

$$
Q_{\mathrm{total}}=(d d / y r)(24 \mathrm{hr} / \text { day }) \sum_{j=1}^{n} U_{\mathrm{j}} A_{\mathrm{j}}
$$

The total heat loss must be increased by about $25 \%$ to account for infiltration losses. Annual fuel consumption is obtained by dividing total heat loss by furnace efficiency $\eta(70-90 \%)$, which should be reduced to take into account heat duct losses of perhaps $20 \%$. The concept of heating degree days is not useful for warmer climates because it ignores daytime storage of energy that is used in the early evening.

\section{Infiltration Losses}

About one-fourth of heat is lost from cold air infiltrating into a house through holes and small cracks. Heat transfer from infiltrating air is given by

$$
d Q / d t_{\text {infil }}=(d m / d t) c \Delta T
$$

where $d m / d t$ is the infiltration rate of air mass and $\mathrm{c}$ is the specific heat of air. The rate of exchanging air in buildings is described in terms of air changes per hour, or ach. A building with an infiltration rate $R_{\mathrm{ACH}}=1$ ach turns over $100 \%$ of its air in 1 hour. This gives

$$
d Q / d t_{\text {infil }}=(V \rho) R_{\mathrm{ACH}} c \Delta T,
$$

where $V \rho$ is the mass of the air in the house (volume $\mathrm{x}$ density). We "integrate" the above equation over a year using the degree-day statistic to get annual heat loss $Q_{\text {infil }}$ for a $140-\mathrm{m}^{2}$ house in St. Louis: 


$$
\begin{gathered}
Q_{\text {infil }}=(V \rho) R_{\mathrm{ACH}} c(d d / y r)(24 \mathrm{hr} / \text { day }) \\
Q_{\text {infil }}=\left(140 \times 2.5 \mathrm{~m}^{3}\right)(1 \mathrm{ach})\left(1.3 \mathrm{~kg} / \mathrm{m}^{3}\right)\left(1004 \mathrm{~J} / \mathrm{kg}^{\circ}{ }^{\circ} \mathrm{C}\right)(24 \mathrm{~h} / \text { day })\left(2800{ }^{\circ} \mathrm{C}-\text { day } / \mathrm{yr}\right) \\
Q_{\text {infil }}=3 \times 10^{10} \mathrm{~J}=30 \mathrm{MBtu} / \mathrm{yr}=5.5 \mathrm{bbl} / \mathrm{yr} .
\end{gathered}
$$

Infiltration costs the average homeowner whose furnace/duct efficiency $\eta=2 / 3$ about $(5.5 \mathrm{bbl} / \mathrm{yr}) /(2 / 3)=8 \mathrm{bbl} / \mathrm{yr}$. Infiltration costs the US about $800 \mathrm{Mbbl} / \mathrm{yr}=2$ $\mathrm{Mbbl} /$ day. If all houses were tightened by $50 \%$ to $0.5 \mathrm{ach}$, the nation would save roughly $1 \mathrm{Mbbl} / \mathrm{day}$, but the level of radon and pollution would be increased. Air-toair heat exchangers can used in superinsulated houses to retain $75 \%$ of the heat in exiting air.

\section{Traditional Windows}

Passive solar energy in buildings depends on glass that transmits sunlight readily, but strongly absorbs $10-\mu$-wavelength infrared radiation from objects at $300 \mathrm{~K}$. The convection and radiation paths are in parallel and have same area, giving an effective resistance

$$
\mathrm{R}_{\mathrm{par}}=\frac{\mathrm{R}_{\mathrm{rad}} \mathrm{R}_{\mathrm{conv}}}{\mathrm{R}_{\mathrm{rad}}+\mathrm{R}_{\mathrm{conv}}}
$$

Convection resistance is larger on inside surfaces than on outside surfaces. Also the radiation $\mathrm{R}$ value is not exactly the same for the two surfaces. Ignoring these differences, the total R-value for one pane of glass is the sum of two equal parallel resistances and the conductive resistance of a thin sheet of glass, or $R_{\text {total }}=2 R_{\text {par }}+$ $R_{\text {cond. }}$ Using approximate SI units, $R_{\text {conv }}=R_{\text {rad }}=0.2, R_{\text {par }}=0.1$ and $R_{\text {cond }}=0.005$ for glass, we obtain $R_{\text {total }}=2(0.1)+0.005=0.205$, in fair agreement with measurements of $R_{\mathrm{SI}}=0.16\left(R_{\mathrm{Eng}}=0.9\right)$ for single-glazed windows.

The conduction R-value for a pane of glass can be ignored since it is much less than the convection and radiation R-values. The glass temperature is between inside and outside temperatures. Our approximation of equal $\mathrm{R}$ values for inside and outside surfaces give a glass temperature of half-way between inside and outside temperatures. A cold room at $60^{\circ} \mathrm{F}$ on a cold day of $0^{\circ} \mathrm{F}$ develops ice on the inside its single-glazed window since the median temperature is $30^{\circ} \mathrm{F}$.

Double-glaze can be approximated by making the four parallel resistances to be the same, which is not true since still air between two sheets of glass makes convection less effective and outside convection is greater than inside convection. Ignoring the Rvalue of glass, we obtain $R_{\text {total-SI }}=4$ x $0.1=0.4\left(R_{\text {total-Eng }} 2.2\right)$, which is fairly close to the measured value of $R_{\text {total-SI }}=0.3$ ( $\left.R_{\text {total-Eng }} 1.6\right)$. This theory doubles the R-value with the second pane of glass, which is too optimistic since the measured ratio is 1.7. Further savings are possible when low-emissivity (low-E) coatings are used to reflect (rather than absorb) IR back into the room. In addition pulled drapes reduce 
convection and radiation losses, particularly in the night when outside temperature is lowest.

Considerable energy is lost through windows. An average living unit has a floor area of $140 \mathrm{~m}^{2}\left(1500 \mathrm{ft}^{2}\right)$ and window area of $20 \mathrm{~m}^{2}\left(15 \%\right.$ of floor area, $\left.225 \mathrm{ft}^{2}\right)$ with an SI U-factor of 4 (English 0.7). The annual window energy loss for a $2800^{\circ} \mathrm{C}$-day $\left(5000^{\circ} \mathrm{F}\right.$-day) heating season in SI units is

$$
(U A)(24)(d d / y r)=\left(4 \mathrm{~W} / \mathrm{m}^{2}-^{\circ} \mathrm{C}\right)\left(20 \mathrm{~m}^{2}\right)(24 \mathrm{hr} / \text { day })\left(2800{ }^{\circ} \mathrm{C} \text {-day }\right)=1.9 \times 10^{10} \mathrm{~J} / \mathrm{yr} .
$$

In practical units this is $18 \mathrm{MBtu} / \mathrm{yr}$, or $3.2 \mathrm{bbl} / \mathrm{yr}$ of oil (equivalent). If furnace/duct efficiency is about $2 / 3$, the total fuel used for windows is $(3.2 \mathrm{bbl} / \mathrm{yr})(3 / 2) \cong 5 \mathrm{bbl} / \mathrm{yr}$. For 100 million US residences the loss of energy through windows is $500 \mathrm{Mbbl} / \mathrm{yr}=$ $1.3 \mathrm{Mbbl} /$ day, or $3 \%$ of total US energy use.

\section{Low-E Windows}

Convection is the dominant heat path for low-E coatings, constraining U-values to $30 \%$ of traditional glass. Low-E coatings are also useful in summer, as they reflect away IR emitted by warm surfaces outside the house and near-IR from the sun. Thus, low-E glass reduces heating in winter and air conditioning in summer. Window manufacturers started making low-E windows in 1991, capturing $35 \%$ of the US market by 1996 .

Low-E windows use materials selected to transmit visible light and reflect, rather than absorb, infrared. Wide-band tin and indium oxide semiconductors can be doped to produce IR reflection. IR reflection can also be done with very thin layers $(10-20$ $\mathrm{nm}$ ) of silver. Reflectivity of low-E windows is based on plasma physics. They exploit a concept known as the plasma frequency, which is the resonant frequency at which electrons will oscillate when displaced a tiny amount with respect to positive ions. In low-E windows, electromagnetic waves above the plasma frequency are transmitted, while EM waves below the plasma frequency are reflected. An example of this is the increased quality of radio transmission at night. Because darkness lacks ultraviolet, the nighttime ionosphere has fewer free electrons at 1000-km altitude, giving a lower plasma frequency of about $3 \mathrm{MHz}$. Since radio waves have a frequency under $3 \mathrm{MHz}$, they are reflected from the ionosphere, allowing radio signals to travel as far as 10,000 $\mathrm{km}$. In low-E windows, the doping level in the semiconductors determines the freeelectron density, analogous to how UV changes free-electron levels in the ionosphere. By increasing doping levels, one can increase the plasma frequency. The low-E materials $\mathrm{SnO}_{2}: \mathrm{F}$ and $\mathrm{In}_{2} \mathrm{O}_{3}: \mathrm{Sn}$ reflect infrared at wavelengths longer than $1.5 \mu$, while transmitting visible light and near IR at wavelengths under $1.5 \mu$. To obtain the $1.5-\mu$ transition, an electron density of $5 \times 10^{26} / \mathrm{m}^{3}$ is chosen to give plasma frequency $(\lambda=$ $c / f=2 \pi c / \omega)$

$$
\omega_{\mathrm{p}}=\left(n \mathrm{e}^{2} / \varepsilon_{\mathrm{o}} m\right)^{1 / 2}=1.3 \times 10^{15} \mathrm{radians} / \mathrm{sec},
$$


where $n$ is electron density, e is electron charge and $\mathrm{m}$ is electron mass, and $\varepsilon_{\mathrm{o}}$ is the permittivity of free space. There are two ways low-E windows can help. In the winter we want to reflect heat back into the room for wavelengths more than a micron or so. During the summer, we would like to reflect thermal IR at the same wavelengths. However, Sun produces considerable energy in the near IR at wavelengths shorter than one micron. There would be less airconditioning if we reflect more near IR away from windows. Present windows favor the winter situation.

\section{Induced Infiltration}

Houses typically are at partial vacuum, typically 4 Pascal below atmospheric pressure. The first cause is stack induced infiltration. The pressure at the top of a chimney or attic of height $h$ is reduced with respect to the ground level by

$$
\Delta p_{\text {stack }}=-\rho g h=-\left(1.3 \mathrm{~kg} / \mathrm{m}^{3}\right)\left(9.8 \mathrm{~m} / \mathrm{sec}^{2}\right) h=-13 h \text { Pascal, }
$$

with $h$ in meters. If this reduction were the only effect, air would not rise, but remain in static equilibrium. But warmed air rises because its density is inversely proportional to its absolute temperature. Warm air rises because it is less dense, gravity pushes it upwards with a pressure difference proportional to the temperature difference.

$$
\Delta p_{\text {temp }} \approx-13 h T_{\mathrm{o}}\left(1 / T_{\mathrm{o}}-1 / T_{\mathrm{i}}\right) \approx-13 h\left(T_{\mathrm{i}}-T_{\mathrm{o}}\right) / T_{\mathrm{i}},
$$

where $T_{\mathrm{o}}$ is outside temperature at the top of the stack, $T_{\mathrm{i}}$ is house inside temperature. At $T_{\mathrm{i}}=20^{\circ} \mathrm{C}=293 \mathrm{~K}$ and $\Delta T=T_{\mathrm{o}}-T_{\mathrm{i}}$,

$$
\Delta p_{\text {temp }}=0.044 h \Delta T_{\mathrm{i}}
$$

For a two-story house with an attic or chimney at $h=10 \mathrm{~m}$ and $T_{\mathrm{o}}=0^{\circ} \mathrm{C}$ in winter, the thermal pressure difference is

$$
\Delta p_{\text {temp }}=(0.044)(10 \mathrm{~m})(-20 \mathrm{~K})=-9 \text { Pascal. }
$$

The air infiltration flow rate $\left(\mathrm{m}^{3} / \mathrm{sec}\right)$ from Bernoulli's theorem is given by

$$
F=\text { area } \mathrm{x} \text { velocity }=A(2 \Delta p / \rho)^{1 / 2} \text {. }
$$

If stack loss is confined to a total area $0.1 \mathrm{~m}$ by $0.1 \mathrm{~m}$, the air loss rate from a temperature-driven pressure difference of 9 Pascal is

$$
F=\left(0.01 \mathrm{~m}^{2}\right)\left(2 \times 9 \mathrm{~Pa} / 1.3 \mathrm{~kg} / \mathrm{m}^{3}\right)^{1 / 2}=0.037 \mathrm{~m}^{3} / \mathrm{sec} .
$$

The energy loss rate is

$$
P=\rho F c \Delta T / \eta=\left(1.3 \mathrm{~kg} / \mathrm{m}^{3}\right)\left(0.037 \mathrm{~m}^{3} / \mathrm{sec}\right)(1.006 \mathrm{~kJ} / \mathrm{kg}-\mathrm{K})(20 \mathrm{~K}) / 1=0.97 \mathrm{~kW}
$$


for electrical heating with $\eta=1$. The fuel rate is $1.2 \mathrm{~kW}$ for a furnace with $\eta=0.8$. This leak costs $30 \mathrm{kWh} /$ day or $\$ 3 /$ day at $10 \notin / \mathrm{kWh}$. For natural gas, it is a loss of $10^{5}$ Btu $/$ day $=1$ therm $/$ day $=\$ 1 /$ day.

Wind-induced infiltration: Wind blowing parallel to a surface reduces pressure at the surface due to the Bernoulli effect. A reduced pressure at the outside surface draws air from the inside through building leaks. The removed air is replaced by cold winter air or warm summer air. Large area leaks have turbulent flows proportional to the square root of the pressure difference between the inside and outside. Minute area leaks have viscous (laminar) air flow related to the square root of the pressure difference. Since buildings have both laminar and viscous flow, the flow rate has to be determined empirically. One way to do that is with a blower door, which can be mounted in the door of house, with all the other doors and windows closed. A blower door fan that produces air flow of $1-2 \mathrm{~m}^{3} / \mathrm{sec}$ can create an overpressure of 100 Pascals within the building. A graph of flow rate $F$ vs. pressure difference $\Delta p$ is fit to $F=\mathrm{k} \Delta p^{n}$, where $n$ is between 0.5 for turbulent flow and 1.0 for laminar flow and $k$ is a constant proportional to effective area. The curve is extrapolated to a 4 Pascal defined pressure difference to determine the effective loss area. Most US houses have leakage areas between $300 \mathrm{~cm}^{2}$ and $1000 \mathrm{~cm}^{2}$. Super-tight houses can be as low as $50 \mathrm{~cm}^{2}$ and old leaky houses can be as high as $3000 \mathrm{~cm}^{2}$.

Besides measuring leaks, blower doors also discover air leaks by over pressurizing houses, which forces air to escape through cracks. The trail of smoke coming from a miner's smoke stick locates leaks, which are then plugged with polystyrene foam. Leaks into an attic are discovered with smoke sticks by under pressurizing a house, that is, sucking air from the attic into the house. In this way blower doors are used to reduce infiltration losses, which at the extremes of weather, can cost $\$ 1500 /$ year in Maine (heating) and Miami (cooling).

\section{HOUSE DOCTORS}

US buildings built before the oil embargo in a time of cheap energy often had no insulation in warm climates like California, or too little insulation in colder climes. A US house before the embargo using oil or gas heat consumed 73 million Btu/yr (77 GJ, 12.5 bbl of oil). In 1990 the average new US house consumed $40 \%$ less energy at 43 million Btu ( $45 \mathrm{GJ}, 7.4 \mathrm{bbl}$ ). Air infiltration is responsible for $20 \%$ of the total loss, and hot air systems lose another $20 \%$ through duct leaks and furnace inefficiency.

In this section we consider the benefits a house gains from occasionally "seeing" a doctor, much as a human body needs occasional visits to a doctor. Princeton University's Center for Energy and Environmental Studies pioneered the concept of the house doctor in the 1970s. Prior to that time there was little scientific study on buildings because industry was very decentralized. The Socolow-Princeton group discovered that attic bypass paths allowed warm air to travel around ceiling insulation through channels in walls to cold attics. At Cal Poly San Luis Obispo, my student, Jim Woolaway, and I followed the Princeton and Berkeley (blower door) work by creating a house doctor laboratory for Cal Poly architecture students. The laboratory was named The Arthur Rosenfeld House Doctor Laboratory for the man who has been the 
main leader in improving energy use in US buildings. My university objected to my naming the Rosenfeld laboratory for a non-donor, but they never made me take the sign down! It is obvious that retrofitting an existing building is more complicated and expensive than constructing it correctly in the first place. However, some energysaving, retrofit measures can be easily carried out. In the 1980 s it was estimated that an investment of $\$ 1000$ would save $25 \%$ of a home heating bill and $\$ 2000$ would save $40 \%$. We will describe the blower-door which measures infiltration and locates leaks.

Small blower doors are used to discover leaks in hot air duct systems. A Lawrence Berkeley National Laboratory group, led by Max Sherman, discovered that a "typical house with ducts located in the attic or crawlspace wastes approximately $20 \%$ to $40 \%$ of heating and cooling energy through duct leaks, and draws approximately 0.5 kilowatts more electricity during peak cooling periods. Sealing leaks could save close to $1 \mathrm{quad} /$ year nationwide." The LBNL group devised a relatively simple repair to fill the leaks in the ducts. An aerosol sealant is sprayed into a closed, overpressurized duct system. The excess pressure pushes the sealant to the leaks, where it collects and plugs them. This is the same approach that is used to seal car radiators, in which a liquid sealant is added to the coolant, which is pushed into the leaks and plugs them.

Superinsulated houses reduce infiltration rates to as low as 0.1 air exchange per hour, but the resultant air may suffer from indoor pollution and radon. Air-to-air heat exchangers transfer the heat in warm exiting air to the cold and clean air entering from outdoors. The efficiency of an air-to-air heat exchanger is as

$$
\eta=\Delta T_{\text {rise }} / \Delta T_{\text {in-outside }}
$$

where $\Delta T_{\text {rise }}$ is the temperature rise of the incoming air through the heat exchanger and $\Delta T_{\text {in-outside }}$ is the temperature difference between inside and outside air. Temperature efficiency varies between $50-85 \%$, depending on design and weather conditions.

Other measurements and devices provided by house doctors include:

- thermoelectric meters to measure heat flow through walls

- infrared temperature scanners to find and quantify thermal leaks

- thermocouple temperatures over the 24-hour cycle

- $\quad \mathrm{kWh}$ meters on appliances

- solar-flux gain and thermal loss meters on windows

- lumens/watt measurements on lighting.

\section{Thermal Simulations}

Engineers, architects and regulators rely on computer simulations to improve building designs and determine if a building satisfies state energy regulations. For example, results of simulations revealed a $\$ 9$ million annual energy savings for a San Francisco federal building if it were to use natural ventilation without fans or air conditioning. This would be accomplished by taking advantage of interior heat that is absorbed during the day on exposed ceiling slabs, which then dissipate heat at night to warm the building. CALPAS (California Passive Solar), originally developed by Phil Niles of Cal Poly, was the first simulation computer program that simulated energy 
aspects of passive solar buildings. It was later enhanced by Bruce Wilcox of the Berkeley Solar Energy Group. Its progeny, DOE-2 and Energy Plus, calculate energy loss in buildings to an accuracy of $10 \%$, using the following features:

- solar gain from windows and skylights

- heat conduction through all surfaces (interior and exterior)

- infiltration of air

- heat gain from occupants, lights, and equipment.

An alternative type of calculation uses the analog of electrical $R C$ networks to determine energy flow and energy storage in buildings. In the analog model voltage is the analog of temperature, electrical current is the analog of heat flow, capacitance is the analog of thermal mass, and electrical resistance is the analog of the product of $R$ value and surface area (but without $i^{2} R$ losses). There is no thermal analog for electrical inductance.

\section{Heat Island Mitigation}

Urban centers of large cities have seen an increase in average higher summer temperatures prior to the 1950s. The trend has increased air conditioning loads and air pollution. The yearly high temperature in downtown Los Angeles at 4 PM rose $3.5^{\circ} \mathrm{C}$ $\left(7^{\circ} \mathrm{F}\right)$ in the past 50 years. This is partially driven by the fact that black asphalt reflectivity is as low as $4 \%$. The heat-island effect could be mitigated with a shift from green shingles to white shingles on house roofs, raising reflectivity from $18 \%$ to $43 \%$ and dropping roof temperature by $10^{\circ} \mathrm{C}\left(21^{\circ} \mathrm{F}\right)$. Higher reflection is possible with $\mathrm{TiO}_{2}$ surfaces, which have a reflectivity of $83 \%$, further reducing roof temperature by another $17^{\circ} \mathrm{C}\left(33^{\circ} \mathrm{F}\right)$. The Los Angles albedo could be raised by 0.08 by planting more trees and an increasing roof reflectivity over $25 \%$ of the city's area. These actions could lower LA downtown temperature in 20 years by $2.5^{\circ} \mathrm{C}\left(5^{\circ} \mathrm{F}\right)$, enough to save 1.5 $\mathrm{GW}_{\mathrm{e}}$ peak power. In similar fashion, the US could reduce the national air conditioning peak load of $100 \mathrm{GW}_{\mathrm{e}}$ by $20 \%$ with increased reflectivity. See chapter in this book by Hashim.

\section{BUILDING ENERGY STANDARDS}

Many studies show a $25 \%$ energy savings on new construction could be realized for little or no net initial cost, since money could be saved by down-sizing air conditioners and heating plants. About 1.7 million new housing units are built each year, but this is only $2 \%$ of all housing stock and it will take 50 years to take full advantage of the energy savings. One-half of the states, which account for two-thirds of new homes, have mandatory energy building codes that are as restrictive as the standards recommended by the American Society of Heating, Refrigeration and Air Conditioning Engineers (ASHRAE). California led the nation with its 1975 energy laws, as it mandates the tightest of US standards. California building standards have to be shown to be cost effective for them to be adopted. A few cities require existing houses to fulfill a minimum energy standard before the houses can be resold. A much 
less restrictive approach is the use of labels that indicate a house's energy saving features and failures. New homes earn an Energy Star if they consume at least 30\% less energy than energy code specifications for heating, cooling and water heating. This represents a savings of some \$300-600/yr [0.3(\$1000-2000/yr)] from code level. See the appendix of this paper on LEED certification for buildings.

\section{Heat/Cold Storage in Large Buildings}

The first successful, proof of principle, passive solar, energy-independent building was built in Atascadero, California by Ken Haggard of Cal Poly University and Harold Hay. Analysis of the Atascadero House was carried out by Philip Niles, creator of the CALPAS passive solar simulation program. ${ }^{2}$ Sweden has developed another approach to produce an almost heat-energy free building. Many Swedish office buildings need very little heat because they use excess daytime heat for nighttime warmth, storing energy in concrete floor and ceiling slabs. To dampen noise, concrete flooring is usually padded, an approach that prevents good thermal contact between the concrete and the inside air. However, Swedish Thermodeck ${ }^{\circledR}$ buildings transfer energy to the interior of the concrete through hollow-core tubes in floor slabs. The tubes are cast into the concrete slabs to reduce slab weight while minimizing mechanical deflections. (I-beams use the same approach to shift mass away from the center of the beam.) Although Stockholm, with $3580^{\circ} \mathrm{C}$-day/yr $\left(6444^{\circ} \mathrm{F}\right.$-day $\left./ \mathrm{yr}\right)$, is colder than Chicago, Thermodeck buildings use only $4 \mathrm{kWh} / \mathrm{ft}^{2}$ of electric resistance heating per year, a cost so low that it is not necessary to hook Thermodecks to the Stockholm district heating system. This system also works well in the summer, using night air to pre-cool buildings.

We begin with energy gains/losses to see if it is possible to operate Thermodeck buildings with essentially no added heat. A single-occupant office is $2.4 \mathrm{~m}$ wide by 4.2 $\mathrm{m}$ deep by $2.7 \mathrm{~m}$ high, for a $10-\mathrm{m}^{2}$ area and $27-\mathrm{m}^{3}$ volume. A cold day in Stockholm of $-9^{\circ} \mathrm{C}\left(16^{\circ} \mathrm{F}\right)$ has an inside-to-outside temperature difference $\Delta T=21^{\circ} \mathrm{C}-\left(-9^{\circ} \mathrm{C}\right)=$ $30^{\circ} \mathrm{C}\left(54^{\circ} \mathrm{F}\right)$. A person's body heat produces $100 \mathrm{~W}$, and lights and machines in an office contribute an additional $300 \mathrm{~W}$. Because Swedish offices must have windows, Thermodeck buildings have a large surface-to-volume ratio, increasing insulation needs. Each office has $1.5 \mathrm{~m}^{2}$ of triple-glazed windows $\left(U_{\mathrm{SI}}=2\right)$ and $5 \mathrm{~m}^{2}$ of wall surface $\left(U_{\mathrm{SI}}=0.25\right)$. Natural infiltration enters in a room at $5 \mathrm{~m}^{3} / \mathrm{hr}$ during unoccupied hours. During the occupied hours infiltration is increased to $20 \mathrm{~m}^{3} / \mathrm{hr}$ to ensure good air quality. Solar gain is a modest $30 \mathrm{~W} /$ room during winter occupied hours.

The heat-transfer rate from infiltration is

$$
d Q / d t=\rho(d V / d t) c \Delta T
$$

where air density $\rho=1.3 \mathrm{~kg} / \mathrm{m}^{3}$, air flow rate is $d V / d t$, air specific heat $c=1000 \mathrm{~J} / \mathrm{kg}$ ${ }^{\circ} \mathrm{C}$ and $\Delta T$ is the inside-to-outside temperature difference. The loss rate during the occupied the hours, when $d V / d t=20 \mathrm{~m}^{3} / \mathrm{hr}=0.0056 \mathrm{~m}^{3} / \mathrm{sec}$, is

$$
d \mathrm{Q} / d \mathrm{t}=\left(1.3 \mathrm{~kg} / \mathrm{m}^{3}\right)\left(0.0056 \mathrm{~m}^{3} / \mathrm{sec}\right)\left(1000 \mathrm{~J} / \mathrm{kg}^{\circ} \mathrm{C}\right)\left(-30^{\circ} \mathrm{C}\right)=-218 \mathrm{~W} .
$$


The infiltration loss rate from a flow of $5 \mathrm{~m}^{3} / \mathrm{hr}$ during unoccupied hours is $54 \mathrm{~W}$. Window loss rate is 90 watts $(U A \Delta T=0.25 \times 5 \times 30)$. Wall loss rate is 38 watts $(2 \times$ $1.5 \times 30)$.

During the day, $430 \mathrm{~W}$ of heat is gained in an office (person $100 \mathrm{~W}$, equipment 300 $\mathrm{W}$, solar $30 \mathrm{~W}$ ), while at night the loss rate is $346 \mathrm{~W}$ (infiltration $218 \mathrm{~W}$, wall $38 \mathrm{~W}$, window 90). The net gain by day is $430 \mathrm{~W}-346 \mathrm{~W}=84 \mathrm{~W}$. During the night there is no gain, while at night the loss rate is $182 \mathrm{~W}$ (infiltration $54 \mathrm{~W}$, wall $38 \mathrm{~W}$, window 90). The net loss by day is $430 \mathrm{~W}-346 \mathrm{~W}=84 \mathrm{~W}$. Heat is transferred in the morning to raise the temperature above $T_{\mathrm{o}}$ from the evening hours. The temperature $T$ of the room air is

$$
T=T_{\mathrm{o}}+(d Q / d t) t / C,
$$

where $C$ is the slab heat capacity $/ \mathrm{m}^{2}$ and $d Q / d t$ is internal heat rate in $\mathrm{W} / \mathrm{m}^{2}$. The heat capacity of the 30 -cm thick slabs is $C=120 \mathrm{Wh} / \mathrm{m}^{2}-{ }^{\circ} \mathrm{C}$, which includes an extra $20 \%$ to account for the heat capacity of walls and furnishings. Using these values, the timedependence of the room temperature is

$$
\begin{gathered}
\text { occupied }\left(8 \mathrm{~W} / \mathrm{m}^{2}\right) \quad T=T_{\mathrm{o}}+0.07 t \\
\text { unoccupied }\left(-18 \mathrm{~W} / \mathrm{m}^{2}\right) \quad T=T_{1}-0.15 t
\end{gathered}
$$

with $t$ in hours. During a 10-hour workday room temperature remains fairly constant, rising by $1^{\circ} \mathrm{C}(0.07 \times 10)$. Overnight room temperature drops by about $2^{\circ} \mathrm{C}(0.15 \times 14)$, a drop that is lessened by adding a little heat to the room.

\section{Thermal Storage to Reduce Peak Power}

Daytime air conditioning could be significantly reduced by taking advantage of the night coolth and the fact that power is cheaper at night. During the deep air conditioning season, chillers are run at night, when electricity is cheaper, to pre-cool slabs. This approach also takes advantage of improved efficiencies from lower night temperatures. Implementing off-peak electricity usage may not give considerable energy savings in terms of $\mathrm{kWh}$, but the tactic does save the expense of daytime peak power charges. Finally, this approach downsizes cooling systems by allowing them to be used on a 24-hour basis.

Internal heat gains are a dominant feature of large buildings, forcing the use air conditioning. This excess demand causes severe daytime summer peak power loads, as much as 2-3 times the nighttime load. The fraction of US homes with air conditioning reached $77 \%$ by 2001 , increasing US peak demand by $2 \mathrm{GW}_{\mathrm{e}} / \mathrm{yr}$. The $5 \% / \mathrm{yr}$ growth

rate for new commercial buildings (replacement plus growth) adds 2.5 billion $\mathrm{ft}^{2} / \mathrm{yr}$ of floor space, driving peak demand by $1.6 \mathrm{GW}_{\mathrm{e}} / \mathrm{yr}$. Residential and commercial air conditioning each used $80 \mathrm{GW}_{\mathrm{e}}$, for a total peak load of $160 \mathrm{GW}_{\mathrm{e}}$. This could be reduced with off-peak cooling with thermal storage.

The headquarters of the Alabama Power Company in Birmingham, Alabama, installed five large ice cells to contain 550 tonnes of ice for cooling for its $110,000-\mathrm{m}^{2}$ 
building. Ice storage on the basis of floor-area density basis is $5 \mathrm{~kg}$ per $1 \mathrm{~m}^{2}$ floor space (550 tonne $/ 110,000 \mathrm{~m}^{2}$ ), with a stored energy density of

$$
Q / \mathrm{m}^{2}=m L_{\text {fusion }}=\left(5 \mathrm{~kg} / \mathrm{m}^{2}\right)\left(3.4 \times 10^{5} \mathrm{~J} / \mathrm{kg}\right)=1.7 \mathrm{MJ} / \mathrm{m}^{2},
$$

where $L_{\text {fusion }}$ is the latent heat to freeze ice. The electrical power $/ \mathrm{m}^{2}$ needed to make ice during 16 off-peak hours is (COP coefficient of performance of 2.5)

$P / \mathrm{m}^{2}=\left(Q / \mathrm{m}^{2}\right) /(C O P)(\Delta t)=\left(1.7 \mathrm{MJ} / \mathrm{m}^{2}\right)(1 \mathrm{kWh} / 3.6 \mathrm{MJ}) /(2.5 \mathrm{x} 16 \mathrm{hr})=12 \mathrm{~W} / \mathrm{m}^{2}$.

Total power required for ice storage is

$$
P=\left(12 \mathrm{~W}_{\mathrm{e}} / \mathrm{m}^{2}\right)\left(1.1 \times 10^{5} \mathrm{~m}^{2}\right)=1.3 \mathrm{MW}_{\mathrm{e}} .
$$

Without thermal storage it would take $2.8 \mathrm{MW}_{\mathrm{e}}$ to cool the building, more than twice the $1.3 \mathrm{MW}_{\mathrm{e}}$ used with ice storage. Coolth stored in ice supplies $2 / 3$ of a day's cooling requirement with $1 / 3$ coming from direct daytime cooling. Since ice storage covers $2 / 3$ of daily summer heat gain, the total daily heat gain in summer is $\left(1.7 \mathrm{MJ} / \mathrm{m}^{2}\right) /(2 / 3)=$ $2.6 \mathrm{MJ} / \mathrm{m}^{2}$. The average summer heat input power $/ \mathrm{m}^{2}$ over 8 hours of daytime is

$$
P / \mathrm{m}^{2}=\left(Q / \mathrm{m}^{2}\right) / t=\left(2.6 \mathrm{MJ} / \mathrm{m}^{2}\right) /(8 \mathrm{hr})(3600 \mathrm{sec} / \mathrm{hr})=90 \mathrm{~W} / \mathrm{m}^{2} .
$$

\section{SCALING LAW FOR BULDINGS}

Energy use by large buildings is load dominated since large buildings have considerable internal heat from equipment, people and lighting. Big buildings have less surface area per unit volume, with internal energy supplying much of the surface losses. This makes large buildings fairly independent of climate while small buildings have energy bills proportional to the heating and cooling degree-days they experience. Energy use in houses is skin dominated since houses must replace heat losses through their envelopes. The physical difference between large and small buildings is easily seen through scaling law relations. Scaling laws for buildings determine the free temperature of buildings as a function of size, as well as for superinsulated houses.

Heat loss is proportional to a cubic building's surface area $6 L^{2}$ and the temperature difference $\Delta T$ between inside and outside:

$$
\mathrm{d} Q / \mathrm{d} t_{\text {loss }}=6 U_{\text {eff }} L^{2} \Delta T,
$$

where $U_{\text {eff }}$ is the effective thermal transmittance $\left(U_{\text {eff }}=1 / R_{\text {eff }}\right)$ for the building that takes into account all energy leaks. On the other hand, internal heat gain is proportional to building volume (floor area times a fixed ceiling height of about $3 \mathrm{~m}$ ):

$$
d Q / d t_{\text {gain }}=G L^{3},
$$

where $G$ is internal heat load per unit volume. A typical house has about $1 \mathrm{~kW}$ of free heat $(3400 \mathrm{Btu} / \mathrm{h})$, while office buildings typically have an internal gain flux on a 
floor-area basis of $f=66 \mathrm{~W} / \mathrm{m}^{2}\left(6 \mathrm{~W} / \mathrm{ft}^{2}\right)$. The volume gain $G$ is $f / H$ where $H$ is the height of one floor, obtained from

$$
d Q / d T_{\text {gain }}=G L^{3}=f n L^{2}=f L^{3} / H,
$$

where the number of floors $n=L / H$. Because of internal gains, the inside of a typical unheated house is $2^{\circ} \mathrm{C}\left(3-4^{\circ} \mathrm{F}\right)$ warmer than the outside temperature.

Let's consider the simple case of walls without mass and specific heat, ignoring the time dependence of warm-up and cool-down. For a building without a furnace, $\Delta T=$ $\Delta T_{\text {free. }}$ We can find the free temperature by requiring the gains and losses to be equal:

$$
\begin{gathered}
d Q / d t_{\text {gain }}=d Q / d t_{\text {loss }}=G L^{3}=6 U_{\text {eff }} L^{2} \Delta T_{\text {free. }} \\
\Delta T_{\text {free }}=G L / 6 U_{\text {eff. }}
\end{gathered}
$$

Thus, $\Delta T_{\text {free }}$ is proportional to the power density $G$ and building length $L$. Large free temperatures are observed in big buildings (large $L$ ), buildings with very good insulation (small $U_{\text {eff }}$ ) and buildings with large internal heat loads (large $G$ ). We will apply the scaling model to large buildings (large $L$ ) and superinsulated houses with considerable insulation (small $U_{\text {eff }}$ ).

A temperature difference is needed to force heat power through the walls. Such is the case of elevated temperatures created by placing a blanket over a $100-\mathrm{W}$ light bulb. The blanket's high thermal resistance blocks heat flow, raising the temperature of the interior of the blanket. The higher interior temperature pushes the 100 thermal watts through the blanket, but it may also start a fire. Free temperature $\Delta T_{\text {free }}$ in buildings can save considerable energy.

Thermostats do not call for extra heat until $T_{\text {outside }}$ drops $\Delta T_{\text {free }}$ below $T_{\text {thermostat }}$ The outside temperature at which the furnace comes on (ignoring time delay from thermal inertia) is called the balance point of a building. The balance point temperature of a typical building is

$$
T_{\text {balance }}=T_{\text {thermostat }}-\Delta T_{\text {free }}=68^{\circ} \mathrm{F}-3{ }^{\circ} \mathrm{F}=65^{\circ} \mathrm{F}=18.3^{\circ} \mathrm{C} .
$$

This temperature is universally chosen as the base temperature in the degree-day formula since the furnace turns on when temperature goes below $T_{\text {balance. At }}$ the balance point, the internal heat gain without the furnace balances the heat losses. As building sizes increases, the increased $\mathrm{d} Q / \mathrm{d} t_{\text {gain }}$ raises $\Delta T_{\text {free }}=G L / 6 U_{\text {eff, lowering the }}$ value of $T_{\text {balance }}$ at which heat is first needed.

At outside temperatures below the balance point, the net heat loss rate is

$$
d Q / d t_{\text {loss }}-d Q / d t_{\text {gain }}=6 U_{\text {eff }} L^{2}\left(\Delta T-\Delta T_{\text {free }}\right)=6 U_{\text {eff }} L^{2}\left(\Delta T-G L / 6 U_{\text {eff }}\right)
$$

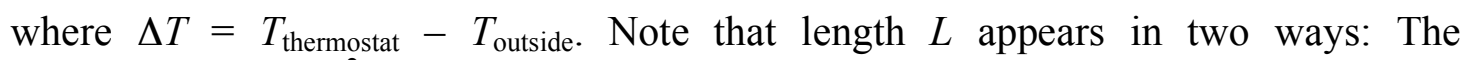
multiplicative $U_{\text {eff }} L^{2}$ term, which is the lossiness of the building, increases with 
conductivity and size. The subtractive $G L / 6 U_{\text {eff }}$ term for free temperature reduces losses by increasing free temperature and lowering the balance point. ${ }^{3}$

Decreased thermal transmittance $\left(U_{\text {eff }}=1 / R_{\text {eff }}\right)$ saves energy in two ways:

(1) Lowering the multiplicative $U_{\text {eff }}$ saves energy proportionally since $d Q / d t_{\text {net }} \alpha$ $U_{\text {eff }} L^{2}$. A superinsulated house can have five times (or more) thermal resistance than a normal house, raising walls from R10 to R50. If this is done for all pathways, $U_{\text {super }}=$ $U_{\text {normal }} / 5$. The multiplicative role of $U_{\text {super }}$, reduces heating bills to $20 \%$ of their former value.

(2) The subtractive free temperature allows houses to be run at effectively lower temperatures. Let the internal energy of a normal house be $1 \mathrm{~kW}(3400 \mathrm{Btu} / \mathrm{h})$ with lossiness $6 U_{\text {eff }} L^{2}=1100 \mathrm{Btu} / \mathrm{h}-{ }^{\circ} \mathrm{F}$. Free temperature is obtained from a heat balance:

$$
1 \mathrm{~kW}=3400 \mathrm{Btu} / \mathrm{hr}=6 U_{\text {eff }} L^{2} \Delta \mathrm{T}_{\text {free }}=\left(1100 \mathrm{Btu} / \mathrm{hr}-{ }^{\circ} \mathrm{F}\right) \Delta T_{\text {free-normal }},
$$

giving $\Delta T_{\text {free-normal }}=3^{\circ} \mathrm{F}$ and $\mathrm{T}_{\text {balance-nomral }}=68^{\circ} \mathrm{F}-3^{\circ} \mathrm{F}=65^{\circ} \mathrm{F}$. A superinsulated house with $20 \%$ of its former lossiness $\left(6 U_{\text {eff }} L^{2}=220\right)$ has a $\Delta T_{\text {free }}$ that is five times larger than a normal house.

$$
\Delta T_{\text {free/super }}=\left(U_{\text {normal }} / U_{\text {super }}\right) \Delta T_{\text {free/normal }}=5 \Delta T_{\text {free } / \text { normal }}=5 \times 3^{\circ} \mathrm{F}=15^{\circ} \mathrm{F}
$$

Considerable energy saving is seen by examining the degree day distribution function for a particular location. For days when $T_{\text {outside }}$ is greater than the balance point of the building, $100 \%$ of the energy is saved. On other days, a fractional energy savings is realized. For example, if the free temperature of a superinsulated house is $15^{\circ} \mathrm{F}$, the balance point is $T_{\text {balance }}=T_{\text {thermostat }}-\Delta T_{\text {free }}=\left(68^{\circ} \mathrm{F}-15^{\circ} \mathrm{F}\right)=53^{\circ} \mathrm{F}$. The furnace is not engaged on days that are warmer than $53^{\circ} \mathrm{F}$, which gives $100 \%$ savings. For a just-freezing day of $32^{\circ} \mathrm{F}$, the furnace supplies $53^{\circ} \mathrm{F}-32^{\circ} \mathrm{F}=21^{\circ} \mathrm{F}$ of what a typical house needs, $65^{\circ} \mathrm{F}-32^{\circ} \mathrm{F}=33^{\circ} \mathrm{F}$, which reduces normal heating bills to $21^{\circ} \mathrm{F} / 33^{\circ} \mathrm{F}=64 \%$. But, we have not included the multiplicative factor of $20 \%$, which gives the actual fuel bill reduction to $64 \% / 5=13 \%$ of its normal value.

Large families with a greater number of occupants that produce and use more thermal power further enhance savings. Twice the thermal output doubles free temperature from $15^{\circ} \mathrm{F}$ to $30^{\circ} \mathrm{F}$. Some super-super insulated houses in Saskatchuwan, Canada, with $\left(10,000{ }^{\circ} \mathrm{F}\right.$-days/yr) use only $\$ 100$ of natural gas to get through the winter. We now see that it is theoretically possible for a house with extremely small lossiness to function with the heat of "two cats fighting," but economics makes this only a pedagogical example.

\section{PASIVE SOLAR BUILDINGS}

Only thermally tight buildings can be successfully solar heated since solar flux is a low-density energy source with average power of $0.2 \mathrm{~kW} / \mathrm{m}^{2}$. Hence, it is good advice to "insulate before you insolate." By a quirk of nature, marvelous glass transmits 
visible light from the sun, while absorbing infrared radiated from inside buildings. Coupling a glass filter with thermal mass gives us low-technology solar heat for buildings and water. Heat capacity of materials allows us to transfer heat from the hotter body to the colder body without moving parts. Passive solar is an essentially free energy source for buildings in warmer climates and it supplies a good boost in cold climates.

Solar energy results from a three-step fusion of four protons into a helium nucleus. The solar flux $s_{\mathrm{o}}$ is a result of the following parameters:

- $\quad$ mass of ${ }^{1} \mathrm{H}$ is 1.0078 AMU and ${ }^{4} \mathrm{He}$ is 4.0026 AMU.

- Earth-sun distance, the astronomical unit (AU), is 150 million $\mathrm{km}$.

- Sun becomes a giant star at $10^{10}$ years when $10 \%$ of $2 \times 10^{30} \mathrm{~kg}{ }^{1} \mathrm{H}$ is consumed.

The mass of four protons is reduced $0.7 \%$ when converted to ${ }^{4} \mathrm{He}$ :

$$
\Delta m / m=(4 \times 1.0078-4.0026) /(4 \times 1.0078)=0.0071=0.7 \% .
$$

The available solar energy over the sun's lifetime is

$$
\Delta M_{\text {sun }} \mathrm{c}^{2}=(0.007)\left(0.1 \times 2.0 \times 10^{30} \mathrm{~kg}\right)\left(3 \times 10^{8} \mathrm{~m} / \mathrm{sec}\right)^{2}=1.3 \times 10^{44} \mathrm{~J} .
$$

The sun's average power over its $10^{10}$ years is

$$
\Delta E_{\mathrm{sun}} / \Delta t=\left(1.3 \times 10^{44} \mathrm{~J} / 10^{10} \mathrm{yr}\right)\left(1 \mathrm{yr} / 3.2 \times 10^{7} \mathrm{sec}\right)=4.1 \times 10^{26} \mathrm{~W},
$$

which gives a solar flux above Earth's atmosphere,

$$
s_{\mathrm{o}}=P_{\mathrm{sun}} / 4 \pi(1 \mathrm{AU})^{2}=\left(4.1 \times 10^{26} \mathrm{~W}\right) /(4 \pi)\left(1.5 \times 10^{11} \mathrm{~m}\right)^{2}=1.5 \mathrm{~kW} / \mathrm{m}^{2} .
$$

The actual solar flux is $10 \%$ smaller at

$$
s_{\mathrm{o}}=1.367 \mathrm{~kW} / \mathrm{m}^{2}=434 \mathrm{Btu} / \mathrm{ft}^{2}-\mathrm{hr}=0.13 \mathrm{~kW} / \mathrm{ft}^{2}=2.0 \mathrm{cal} / \mathrm{min}-\mathrm{cm}^{2} .
$$

The solar flux at Earth's surface is reduced by three factors of 2: (1) daytime angles, (2) nighttime darkness and (3) reflection and absorption by atmosphere and clouds. The first factor of 2 comes from an average of $\cos \theta$ over a hemi-sphere, where $\theta$ is the sun's angle from the zenith position. The second 2 results from 12 hours of darkness for each average day. The combined factor of $2^{2}=4$ reduction is easily grasped. The area of Earth's disk intercepting sunlight is $\pi R_{\mathrm{E}}^{2}\left(R_{\mathrm{E}}=\right.$ Earth radius), but rotation spreads sunlight over 24 hours onto Earth's $4 \pi R_{\mathrm{E}}{ }^{2}$ spherical area, which is four times the disk area. The third factor of 2 is an average of atmospheric absorption and reflection from atmosphere and clouds. The three factors of 2 reduce above Earth solar flux from $1.37 \mathrm{~kW} / \mathrm{m}^{2}$ to $0.2 \mathrm{~kW} / \mathrm{m}^{2}$ for the lower-48 average solar power. 
Solar flux at noon can be estimated from the solar angle $\theta$, which is determined from a location's latitude, and day of the year. Knowledge of $\theta$ is used to determine atmospheric absorption/scattering, cosq for horizontal flux and sinq for vertical flux. Earth's spin axis is tipped $23^{\circ}$ with respect to the plane of the ecliptic. The tip angle, combined with latitude angle $\theta_{\mathrm{L}}$, gives us the solar angle with respect to the zenith at solar noon $\left(\theta_{\text {noon }}\right)$ for four key days, the two solstice and two equinox days: $\theta_{\text {noon }}=\theta_{\mathrm{L}}$ (spring and fall equinox), $\theta_{\text {noon }}=\theta_{\mathrm{L}}-23^{\circ}$ (summer solstice) and $\theta_{\text {noon }}=\theta_{\mathrm{L}}+23^{\circ}$ (winter solstice). San Diego at $33^{\circ} \mathrm{N}$ has $\theta_{\text {noon }}$ varying between $10^{\circ}$ and $56^{\circ}$, while Seattle at $47^{\circ} \mathrm{N}$ has $\theta_{\text {noon }}$ varying between $24^{\circ}$ and $70^{\circ}$. The value of $\theta_{\text {noon }}$ for other days is obtained by fitting a sine function to $\theta_{\text {noon }}$ values for equinox and solstice days. San Diego has 14 hours of sun in the summer and 10 hours in winter. Seattle's lower sun angle is countered by 16 hours of sun in the summer, but winter is both darker and shorter at 8 hours. Everywhere on equinox days the sun rises due east and 12 hours later it sets due west.

The solar flux above the atmosphere $s_{\mathrm{o}}$ is reduced to $s_{1}$ by absorption and scattering from air and clouds, an affect which increases with the zenith angle. Solar flux on a surface is further reduced to $s_{\mathrm{h}}$ by a factor of $\cos \theta$ on horizontal surfaces and to $s_{\mathrm{V}}$ by a factor of $\sin \theta$ on vertical surfaces facing the sun. $A_{\mathrm{o}}$ is an area that is orthogonal to solar rays. The horizontal surface that captures all the rays passing through $A_{\mathrm{o}}$ is a larger area $A_{\mathrm{h}}$. The cosine of $\theta$ relates $A_{\mathrm{h}}$ to $A_{\mathrm{o}}$ by $\cos \theta=A_{\mathrm{o}} / A_{\mathrm{h}}$, giving $s_{\mathrm{h}}=s_{1} \cos \theta$. For vertical surfaces facing the sun, such as windows for passive solar energy, solar flux $s_{1}$ is reduced to $s_{\mathrm{V}}=s_{1} \sin \theta$. Solar energy gathered by solar collectors depends on many variables: latitude of collectors, time of day, season of the year, angle of collectors and materials and equipment used for the collectors. These results must be integrated over the daytime, since passive solar energy is concerned with integrated solar flux and not instantaneous flux. All of this can make calculations difficult, but our approximate methods obtain an accuracy of about $10 \%$.

\section{Atmospheric Transmission}

We return to the reduction of $s_{0}$ to $s_{1}$, as air and clouds reflect and absorb sunlight before it reaches the ground. When the sun is at solar angle $\theta$ from the zenith, its rays pass through more air than when it is at the zenith position. The surface mass density $\left(\mathrm{kg} / \mathrm{m}^{2}\right)$ traversed by light is given in units of $n$ Earth air masses, which increases from $n=1$ at a vertical $\theta=0^{\circ}$ to infinity at a horizontal $\theta=90^{\circ}$ (flat Earth error). The ratio of path lengths in air gives

$$
n=\sec \theta=1 / \cos \theta \text {. }
$$

When the sun is low in the sky at $\theta=60^{\circ}$, mass traversed is doubled, as in $n=$ $1 / \cos 60^{\circ}=1 / 0.5=2$. When the sun is very low at $\theta=80^{\circ}$, the mass traversed is increased by $n=1 / \cos 80^{\circ}=5.7$.

A doubling of air mass to $n=2$ does not double absorption, as additional air absorbs less effectively. The solar flux absorbed, $\Delta s$, in a small amount of mass $\Delta m$ is 


$$
\Delta s=-\lambda s \Delta m
$$

where $\lambda$ is an absorption constant. This integrates to

$$
s_{1}=s_{\mathrm{o}} e^{-\lambda m}
$$

where $s_{0}$ is the initial solar flux. This is the orthogonal solar flux, with the area perpendicular to the solar rays. The path integral of mass density of air traversed by sunlight increases with $\theta$,

$$
m=n m_{\mathrm{o}}=m_{\mathrm{o}} \sec \theta
$$

where $m_{\mathrm{o}}$ is the air mass traversed at $\theta=0^{\circ}$. This allows us to write a general expression for the solar flux at angle $\theta$ from the zenith position:

$$
s_{1}=s_{\mathrm{o}} \exp \left(-\lambda m_{\mathrm{o}} \sec \theta\right)
$$

The value of $\lambda m_{\mathrm{o}}$ is determined from the flux above the atmosphere $\left(s_{\mathrm{o}}=1367 \mathrm{~W} / \mathrm{m}^{2}\right)$ and the maximum flux at Earth's surface $\left(s_{1}=970 \mathrm{~W} / \mathrm{m}^{2}\right)$ when the sun is in the zenith, giving

$$
s_{1}=970 \mathrm{~W} / \mathrm{m}^{2}=1367 \mathrm{~W} / \mathrm{m}^{2} \exp \left(-\lambda m_{\mathrm{o}}\right)
$$

This gives $\lambda m_{\mathrm{o}}=0.34$, which gives solar flux at sea level as a function of $\theta$,

$$
s_{1}=s_{\mathrm{o}} e^{-0.34 \sec \theta}=s_{\mathrm{o}} e^{-1 / 3 \cos \theta} .
$$

This can be corrected for site elevation, which depends on the exponential density of air as a function of elevation.

\section{Angle of Collector}

Horizontal collector flux is reduced from $s_{1}$ by $\cos \theta$,

$$
S_{\mathrm{h}}=\left(s_{\mathrm{o}} \cos \theta\right) e^{-1 / 3 \cos \theta} \text {. }
$$

Passive solar energy in winter relies on vertical, south-facing glass, which has a flux at solar noon of

$$
S_{\mathrm{V}}=\left(s_{\mathrm{o}} \sin \theta\right) e^{-1 / 3 \cos \theta}
$$

Collectors are typically raised toward the south by an angle $\phi$ above the horizontal, giving a flux at solar noon of 


$$
s_{\text {noon }}=\left[s_{\mathrm{o}} \cos (\theta-\phi)\right] e^{-1 / 3 \cos \theta} .
$$

\section{Sun at $\theta=0^{\circ}$ and $60^{\circ}$}

When the sun is in the zenith position $\left(\theta=0^{\circ}\right)$, solar flux is reduced to

$$
s_{\text {zenith }}=s_{0} e^{-1 / 3 \cos \theta}=s_{0} e^{-1 / 3 \cos 0}=0.72 s_{\mathrm{o}} .
$$

Thus, $s_{\mathrm{o}}$ is reduced by $28 \%$, from 434 to $312 \mathrm{Btu} / \mathrm{ft}^{2}-\mathrm{hr}$ (in units familiar to architects) and from 1.37 to $0.98 \mathrm{~kW} / \mathrm{m}^{2}$ (for electrical engineers). Sun rays at $\theta=60^{\circ}$ pass through 2 atmospheres, giving

$$
s_{1}=s_{\mathrm{o}} \mathrm{e}^{-1 / 3 \cos 60}=s_{\mathrm{o}} \mathrm{e}^{-1 / 1.5}=0.51\left(434 \mathrm{Btu} / \mathrm{ft}^{2}-\mathrm{hr}\right)=220 \mathrm{Btu} / \mathrm{ft}^{2}-\mathrm{hr} .
$$

The solar flux incident on horizontal collectors at solar noon is further reduced by $\cos 60^{\circ}=0.5$ to $s_{\mathrm{H}}=220 / 2=110 \mathrm{Btu} / \mathrm{ft}^{2}-\mathrm{h}$. Note that flux on south-facing vertical windows at solar noon is not reduced nearly as much as on the horizontal, as $s_{\mathrm{V}}=$ $\left(0.51 s_{\mathrm{o}}\right)\left(\sin 60^{\circ}\right)=220 \times 0.87=191 \mathrm{Btu} / \mathrm{ft}^{2}-\mathrm{hr}$. The resilience of vertical flux in winter is a tremendous aid to passive solar heating. When snow is on the horizontal ground, the solarium with vertical glass can be warm. At noon on December 21 in Minneapolis $\left(45^{\circ} \mathrm{N}, \theta=68^{\circ}\right)$, the horizontal flux is reduced to $66 \mathrm{Btu} / \mathrm{ft}^{2}-\mathrm{hr}$ while south-facing windows receive a respectable $163 \mathrm{Btu} / \mathrm{ft}^{2}-\mathrm{hr}$ on a cloudless day.

\section{Integrated Solar Flux}

Integrated solar flux over daytime hours is relevant for solar heated water or buildings. The thermal mass of water and cement respond slowly, as they are not responsive to instantaneous flux. A plot of solar flux versus time is approximately the first half-cycle of a sine function. Therefore, we approximate the direct solar flux as a sine function, ignoring the indirect, diffuse component, scattered from the entire sky:

$$
s_{\text {direct }}=s_{\text {noon }} \sin (2 \pi t / T) \text {. }
$$

The maximum amplitude $s_{\text {noon }}$ is the flux on the south-facing collector at solar noon with sunrise at $t=0$ and sunset at $t=T / 2$. The value of $\mathrm{T}$ is set by location and time of year such that $\mathrm{T} / 2$ gives the length of the daylight period. Note that the equinox daylight is $T / 2=12$ hours ( $T=24$ hours) at all latitudes. The summer day is $T / 2=14$ hours at $30^{\circ}$ latitude and 16 hours at $45^{\circ}$ latitude. The winter day is $T / 2=10$ hours at $30^{\circ}$ and 8 hours at $45^{\circ}$. Note that vertical surfaces have a much higher flux in winter as compared to summer, due to the increased value of $\sin \theta$.

Horizontal integrated solar flux at equinox at $30^{\circ} \mathrm{N}$ with $T / 2=12$ hours and $s_{\mathrm{h} \text {-noon }}$ $=255 \mathrm{Btu} / \mathrm{ft}^{2}-\mathrm{hr}$ is 


$$
I=\int_{0}^{T / 2} S_{\mathrm{h}} d t=\int_{0}^{T / 2} S_{\mathrm{h}-\mathrm{noon}} \sin (2 \pi t / T) d t=s_{\mathrm{h}-\mathrm{noon}} T / \pi=255 \times 24 / \pi=1950 \mathrm{Btu} / \mathrm{ft}^{2}-\mathrm{d} .
$$

The equinox value is almost equally bracketed by the summer solstice value of $2800 \mathrm{Btu} / \mathrm{ft}^{2}$-day and the winter solstice value of $970 \mathrm{Btu} / \mathrm{ft}^{2}$-day. Horizontal collectors give very wide variations of integrated flux during a year, as the daily flux at $30^{\circ} \mathrm{N}$ latitude varies by a factor of 2.9 during the year while the collector at $45^{\circ}$ varies by a factor of 8 . Raised collectors at $\theta_{\mathrm{L}}+15^{\circ}$ have a much smaller variation, with a factor of 1.4 at $30^{\circ}$ and 2.6 at $45^{\circ}$. But this can be misleading if seasonal clouds are significant. The average daily-integrated flux is about one-fourth the sum of the dailyintegral fluxes of two solstices and two equinoxes.

Since active solar space heating is needed only in the winter, the winter season is favored by raising the collector towards the south above the horizontal by $15^{\circ}$ plus the local latitude. This angle is close to the extreme value of $23^{\circ}$ plus the latitude ( $\theta$ at solar noon on December 23). On the other hand, solar hot water is needed during the entire year so the collectors are raised at the latitude angle, which takes advantage of solar oscillation to either side of the equinox position. However, in the winter mode the collectors are usually needed at an angle of $15^{\circ}$ plus latitude. This is the angle that is usually used for stationary collectors because (1) winter days are shorter, (2) the winter sun is weaker and (3) winter feed water is colder.

\section{Passive Solar Window Gains and Losses}

Glass transmits solar energy and reflects and retains infrared heat for basic passive solar energy as part of glass plus mass. The energy gains and losses through southfacing windows in winter are now calculated to evaluate the efficiency of passive solar energy. We begin again with a favorable location in a moderate climate, San Luis Obispo, California, which has few cloudy days in winter. We assume the following:

- double-glaze window, $U=0.5 \mathrm{Btu} / \mathrm{ft}^{2}-\mathrm{hr}$

- $55^{\circ} \mathrm{F}$ outside temperature in winter

- $90 \%$ transmission through

- winter flux, south-facing window, $s=\left(270 \mathrm{Btu} / \mathrm{ft}^{2}-\mathrm{hr}\right) \sin (2 \pi t / T)$ and $T / 2=10$ hours.

The daily heat loss is

$$
Q_{\text {loss }} / A=U \Delta T \Delta t=\left(0.5 \mathrm{Btu} / \mathrm{ft}^{2}-\mathrm{hr}\right)\left(65^{\circ} \mathrm{F}-50^{\circ} \mathrm{F}\right)(24 \mathrm{hr})=180 \mathrm{Btu} / \mathrm{ft}^{2}-\mathrm{d} .
$$

The daily solar energy gain is

$$
Q_{\text {gain }} / A=0.9 S_{\mathrm{v}} T / \pi=(0.9)\left(270 \mathrm{Btu} / \mathrm{ft}^{2}-\mathrm{hr}\right)(20 \mathrm{hr}) / \pi=1550 \mathrm{Btu} / \mathrm{ft}^{2}-\mathrm{d} .
$$

The ratio $Q_{\text {gain }} / Q_{\text {loss }}=1550 / 180=8$ is favorable and could be further improved by using drapes or R11 Venetian blinds at night, or by R4 windows. Passive solar heating 
can be used in more severe climates as a partial energy source that reduces energy demand.

\section{THERMAL FLYWHEEL}

Adobe buildings are similar to engine flywheels, which smooth power variations from internal combustion explosions. Massive adobe construction smoothes - or flattens - the temperature cycle of the Southwest by bringing excess day heat for cool nights, and excess night coolth to moderate warm days. Prior to the oil embargo, light, 2-by-4 construction without mass or insulation failed to smooth the temperature cycle.

To illustrate this idea, the thermal time constant of 9 -inch diameter water pipes is determined to see if these pipes can adequately shift day heat into the night. To simplify the mathematics we idealize outside temperature as a square wave cycle with outside temperatures that jump $20^{\circ} \mathrm{F}$ above $70^{\circ} \mathrm{F}$ room temperature for 12 -hour days, then $20^{\circ} \mathrm{F}$ below room temperature for 12-hour nights. How long will the water tubes retain warmth? Will the tubes slowly drop to a reasonable temperature of $70^{\circ} \mathrm{F}$ over a 12-hour period? Will the time constant $\tau$ be too short or will it be pleasant?

We ignore small temperature variations over storage volume, giving a stored energy

$$
Q=W c \Delta T
$$

where $W$ is water weight, $c$ is water specific heat and $\Delta T$ is temperature difference between water and room. For simplicity, the temperature differential $\Delta T=T_{\text {tube }}-T_{\text {room }}$ is denoted below as $T$, the temperature above room temperature. Heat loss from stored energy is the time derivative of $Q$, that is

$$
d Q / d t=W c d T / d t .
$$

Heat loss comes mostly from radiation and convection:

$$
d Q / d t \cong A\left(U_{\text {conv }}+U_{\text {rad }}\right) \Delta T=A U_{\text {total }} \Delta T,
$$

where $A$ is tube surface area for a one-foot length and $U_{\text {total }}$ is the sum of radiation and convection U-factors. Equating the surface loss rate to the loss rate of stored energy inside gives

$$
d Q / d t=A U_{\text {total }} T=-W c d T / d t,
$$

which has an exponential solution, $T=T_{\mathrm{o}} e^{-t / \tau}$ with a thermal relaxation time

$$
\tau=W c / A U_{\text {total }} .
$$

Large heat capacity $\left(W_{c}\right)$ gives a long relaxation time, while a large loss conductance $\left(A U_{\text {total }}\right)$ gives a short relaxation time. The numerator weight $\mathrm{x}$ specific heat $\left(W_{c}\right)$ is 
proportional to stored energy, and the denominator area $\mathrm{x}$ transmittance $\left(A U_{\text {total }}\right)$ is proportional to energy loss rate of stored energy. The value of $\tau$ for 9 -inch water tubes is

$$
\tau=W c / A U_{\text {total }}=(28 \mathrm{lb})\left(1 \mathrm{Btu} / \mathrm{lb}^{\circ}{ }^{\circ} \mathrm{F}\right) /\left(2.4 \mathrm{ft}^{2}\right)\left(1.0 \mathrm{Btu} / \mathrm{ft}^{2}-\mathrm{hr}-{ }^{0} \mathrm{~F}\right)=12 \mathrm{hr},
$$

where weight is 28 pounds/ft, area is $2.4 \mathrm{ft}^{2} / \mathrm{ft}$ with $U_{\text {total }}=1$. The 12-hour relaxation time is the correct choice to effect transfer of day heat to the night.

The energy stored per foot of tube, heated to $80^{\circ} \mathrm{F}$, is

$$
\Delta Q / \mathrm{ft}=W c \Delta T=(28 \mathrm{lb} / \mathrm{ft})\left(1 \mathrm{Btu} / \mathrm{lb}-{ }^{\circ} \mathrm{F}\right)\left(80^{\circ} \mathrm{F}-70^{\circ} \mathrm{F}\right)=280 \mathrm{Btu} / \mathrm{ft} .
$$

This energy/foot is shed overnight,

$$
\Delta Q / \mathrm{ft}=A U_{\text {total }} \Delta T \Delta t=\left(2.4 \mathrm{ft}^{2}\right)\left(1 \mathrm{Btu} / \mathrm{ft}^{2}-\mathrm{hr}-{ }^{\circ} \mathrm{F}\right)\left(80^{\circ} \mathrm{F}-70^{\circ} \mathrm{F}\right)(10 \mathrm{hr})=240 \mathrm{Btu} / \mathrm{ft} .
$$

The heat loss through the house envelope during a 12-hour night, $\Delta Q /$ night, is

$$
\left(600 \mathrm{Btu} / \mathrm{hr}{ }^{\circ} \mathrm{F}\right) \Delta T \Delta t=\left(600 \mathrm{Btu} / \mathrm{hr}^{\circ}{ }^{\circ} \mathrm{F}\right)\left(70^{\circ} \mathrm{F}-50^{\circ} \mathrm{F}\right)(12 \mathrm{hr})=1.4 \times 10^{5} \mathrm{Btu} .
$$

The length of tube needed to replace the lost heat is

$$
\left(1.4 \times 10^{5} \mathrm{Btu} / \text { night }\right) /(240 \mathrm{Btu} / \mathrm{ft}-\mathrm{night})=500 \mathrm{ft} .
$$

A $1500-\mathrm{ft}^{2}$ house with eight rooms requires $60 \mathrm{ft}$ of water tubes per room. By following the adage, "insulate before you insolate," tube length can be reduced by using more insulation and closing infiltration paths. The solar energy available to heat the water is about $50 \%$ of the integrated solar flux $2000 \mathrm{Btu} / \mathrm{ft}^{2}$-day:

$$
\Delta \mathrm{Q}_{\text {solar }} / \mathrm{ft}=\eta I A=(0.5)\left(2000 \mathrm{Btu} / \mathrm{ft}^{2}-\mathrm{day}\right)\left(0.75 \mathrm{ft}^{2} / \mathrm{ft}\right)=750 \mathrm{Btu} / \mathrm{ft},
$$

which is more than sufficient to raise the tube temperature to $80^{\circ} \mathrm{F}$ with $280 \mathrm{Btu} / \mathrm{ft}$.

\section{APPENDIX: LEED CERTIFICATION}

The U.S. Green Building Council (USGBC) began in 1993 to establish programs and building standards to produce buildings that save energy and reduce impacts on the environment A large part of this effort has been to develop the criteria for energysaving buildings under the framework of the Leadership in Energy and Environmental Design (LEED) program. This material in this appendix was obtained from USGBC web site at www.usgbc.org.

\section{Forward from the Green Building Council}

The built environment has a profound impact on our natural environment, 
economy, health and productivity. Breakthroughs in building science, technology and operations are now available to designers, builders, operators and owners who want to build green and maximize both economic and environmental performance. The U.S. Green Building Council (USGBC) is coordinating the establishment and evolution of a national consensus effort to provide the industry with tools necessary to design, build and operate buildings that deliver high performance inside and out. Council members work together to develop industry standards, design and construction practices and guidelines, operating practices and guidelines, policy positions and educational tools that support the adoption of sustainable design and building practices. Members also forge strategic alliances with key industry and research organizations, federal government agencies and state and local governments to transform the built environment. As the leading organization that represents the entire building industry on environmental building matters, the Council's unique perspective and collective power provides our members with enormous opportunity to effect change in the way buildings are designed, built, operated and maintained. The Council's greatest strength is the diversity of our membership. The USGBC is a balanced, consensus nonprofit representing the entire building industry, consisting of over 11,000 companies and organizations. Since its inception in 1993, the USGBC has played a vital role in providing a leadership forum and a unique, integrating force for the building industry

Committee-Based. The heart of this effective coalition is our committee structure in which volunteer members design strategies that are implemented by staff and expert consultants. Our committees provide a forum for members to resolve differences, build alliances and forge cooperative solutions for influencing change in all sectors of the building industry.

Member-Driven. The Council's membership is open and balanced and provides a comprehensive platform for carrying out important programs and activities. We target the issues identified by our members as the highest priority. We conduct an annual review of achievements that allows us to set policy, revise strategies and devise work plans based on member needs.

Consensus-Focused. We work together to promote green buildings and in doing so, we help foster greater economic vitality and environmental health at lower costs. The various industry segments bridge ideological gaps to develop balanced policies that benefit the entire industry.

The rating system is organized into five environmental categories: Sustainable Sites, Water Efficiency, Energy \& Atmosphere, Materials \& Resources, and Indoor Environmental Quality. An additional category, Innovation \& Design Process, addresses sustainable building expertise as well as design measures not covered under the five environmental categories. The main issues covered are as follows: site selection, community connectivity, brownfield redevelopment, public transport, bicycle storage, low-emitting and fuel efficient vehicles, parking capacity, protect and restore habitat, maximize open space, stormwater quantity and quality, heat island, light pollution, water efficient landscapes, innovative wastewater, water-use reduction, optimize energy performance, on-site renewable energy, refrigerant management, measurement and verification, green power, collection of recyclables, rapidly renwable materials, certified wood, air delivery, ventilation, low-emitting 
materials, thermal comfort, and so forth.

The LEED for new construction ratings are awarded according to this scale:

Certified: $\quad 26-32$ points

Silver: $\quad 33-38$ points

Gold: $\quad 39-51$ points

Platinum: $\quad$ 52-69 points

USGBC will recognize buildings that achieve one of these rating levels with a formal letter of certification and a mountable plaque.

A brief example of the many options to optimize energy performance: Whole Building Energy Simulation (1-10 Points). Demonstrate a percentage improvement in the proposed building performance rating compared to the baseline building performance rating per ASHRAE/IESNA Standard 90.1-2004 by a whole building project simulation using the Building Performance Rating Method in Appendix G of the Standard. The base-line energy performance is obtained from California Energy Code (Title XXIV) and other factors. The minimum energy cost savings percentage for each point threshold is as follows for new buildings (percent-saved and points awarded): (10.5\%, 1 point), (14\%, 2 points), (17.5\%, 3 points), (21\%, 4 points), (24.5\%, 5 points), (28\%, 6 points), (31.5\%, 7 points), $(35 \%, 8$ points), $(38.5 \%, 9$ points), (42\%, 10 points).

\section{BIBLIOGRAPHY}

E. Adams (ed.), Alternate Construction, John Wiley, New York (2000).

Amer. Coun. Energy Efficient Economy, Energy Efficiency, ACEEE, Washington, DC (1984-2008).

American Institute of Architects, Energy Design Handbook, AIA Press, Washington, DC (1993).

B. Anderson, Solar Buildings and Architecture, MIT Press, Cambridge, MA (1990).

D. Hafemeister, Physics of Societal Issues, Springer, New York (2007).

M. Krarti, Energy Audit of Building Systems, CRC Press, Boca Raton (2000).

E. Mazria, The Passive Solar Energy Handbook, Rodale, Emmaus, PA (1979).

A. Meinel and M. Meinel, Applied Solar Energy, Addison Wesley, Reading, MA (1979).

US Energy Info. Admin, A Look at Residential Energy Consumption, EIA, Washington, DC (1999).

${ }^{1}$ US home heating modes in $(2000 / 1980 / 1960 / 1940)$ in \% of use: natural gas $(51 / 53 / 43 / 11)$, electricity $(30 / 18 / 2 / 0)$, oil $(9 / 18 / 32 / 10)$, bottled gas $(7 / 6 / 5 / 0)$, coal $(0.1 / 0.6 / 12 / 55)$, wood $(2 / 3 / 4 / 23)$, solar $(0.04 / 0 / 0 / 0)$ [US Census Bureau].

${ }^{2}$ P. W. Niles, "Thermal Evaluation of a house using a movable-insulation heating and cooling system," Solar Energy vol. 18, 413-419 (1976).

${ }^{3}$ In equation 41 , it might seem that one could cancel the $6 \mathrm{U}_{\text {eff }}$ in front with the $6 \mathrm{U}_{\text {eff }}$ in the denominator of the second term. This is mathematically pleasant, but it can't be done since it is a physical two-step process negating the concept of free temperature. 